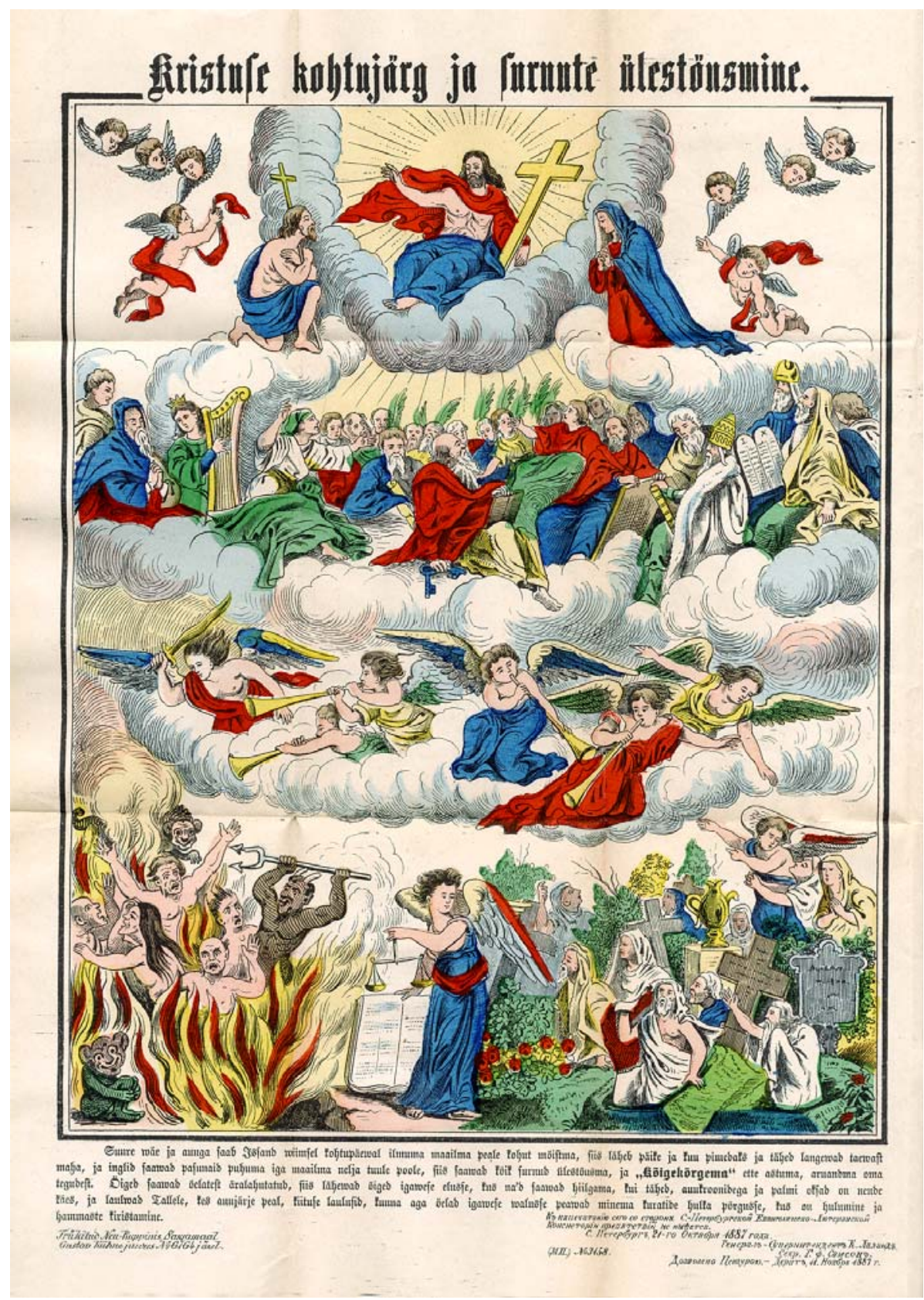

Illustratsioon 1. 19. sajandi lõpus ja 20. sajandi alguses kasutati paljudes eesti kodudes piibliainelisi pilte seinakaunistusena. Viimsest kohtupäevast kõnelev plakat levis A. E. Brandti raamatukese Kristuse kohtujärg ja surnute ülestõusmine. Uus-Jerusalemm 2. osa lisana 1887. 


\title{
Meie maakera viimased minutid
}

\begin{abstract}
Mare Kõiva
Teesid: Artiklis võrreldakse rahvapäraseid maailmalõpuendeid prohvetite ennustustega. Mõlemad traditsioonid peegeldavad ühiskondlikke ja kultuurilisi muutusi, viimsepäevahirmud integreerivad üha uusi seletusviise ja hävingupõhjusi. Jätkuvalt on olulisel kohal astronoomilised taevanähtused, kuid uuemad astronoomia, füüsika, geneetika jt teaduste avastused on täiendanud oluliselt ka maailmalõpumärkide loetelu. Viimase sajandi jooksul on eendunud ennustused maailmalõpust, mille vallandab inimese käitumine. Maailmalõpuended toovad kindlaid tähtpäevi ja esindavad kindlaid poliitilisi või ideoloogilisi suundi ning on seotud sotsiaalsete normidega, mille muutumine neid esile kutsub. Prohvetisõnumite hulgas on stereotüüpseid väljendeid ja endeid, mida on adapteeritud ja omistatud erinevatele isikutele. Karl Tõnissoni 1907. aastal trükitud lendleht Meie maakera viimased minutid kujutab endast Piibli kirjakohtade põhjal arendatud poliitilis-apokalüptilist arutlust, mida toetavad viited teadustöödele. Lendleht on illustreeritud viie puulõikega. Autor loeb saabuva maailmalõpu enneteks Lissaboni 1795. aasta maavärina, pimeda päeva Uus-Inglismaal 1780. aastal ja leoniidide tormi Ameerikas 1833. aastal. Arutlused erinevad hilisematest enesekesksetest poliitilistest fantaasiatest Pan-Baltoonia teemadel, samuti budismiga sulandunud omausundi loomiseks kirjutatud raamatukeste ideoloogiast ja retoorikast.
\end{abstract}

Märksõnad: lendleht, maailmalõpp, Meie maakera viimased minutid, prohvetid, prohvetikuulutus, Karl Tõnisson

\section{Sissejuhatus}

Karl August Tõnissoni (20.08.1873 Umbusi - 05.05.1962 Ranguun) koostatud ja illustreeritud lendleht Meie maakera viimased minutid (Tõnisson 1907) innustas mind vaatlema 20. sajandi maailmalõpuennustusi. Suulisest pärimusest jäädvustatud maailmalõpuennete kõrval on rahvaluulearhiivis hoiul prohvetite lähikondsete ümberkirjutuste ja nende mälestuste vahendusel säilinud teave prohvetiseeringutest, harvemad on prohvetite omakäelised kirjapanekud. Ended, prohvetisõnumid, nägemused ja lühikesed elukäigud moodusta- 
vad usuelu puudutava allikarea, mille abil saame vaadelda muutusi sõnumite retoorikas ja sotsiaalsetes tähendustes, seda muutumatu invariantse põhisõnumi raames.

Lähtudes seisukohast, et narratiivid on arhetüüp, fundamentaalne moodus maailmast rääkimiseks (Georgakopoulou 2007: 27) ning ühe isiku narratiivid ja trükised asetuvad teiste samalaadsete trükiste ja varasema traditsiooni konteksti, saame konkreetse lendlehe paigutada üldisemasse diskursusse. Trükises väljendatud maailmaseletused on osa jagatud vaimsest ressursist, mis on suhestatud omakorda varasemate lugudega. Maailmalõpuended on ka vähemalt osaliselt igapäevased tavateadmised, millest hargnevad käibetõed ja käibelood on kaetud sotsiaalse praktikaga. Selle haru teise osa moodustavad prohvetite maailmalõpuended. Need on harilikult laiema sotsiaalse kriitika või ideoloogia üks osa, individualiseeritud pikemad narratiivid. Neid lugusid iseloomustab isikliku ja kollektiivse ajaloo meenutamine, mis on rikastatud mentaalsete ja usuliste väärtuste esiletõstmisega.

Meie maakera viimased minutid on näide usuteemalistest arutlustest. Lendlehe formaadis pisitrükisena avaldatud prohvetiseering on olemuselt lähedane käsikirjaliste religioossete kettkirjade ja usu-uuenduste pinnalt võrsunud taevakirjade-kaitsekirjade traditsioonile. Lendlehe autor Karl Tõnisson on Eesti kontekstis laiemalt tuntud kui üks esimesi budismi seisukohtade levitajaid. Tema tee budismini sarnaneb teiste 20. sajandi alguse sekulariseeuvas ühiskonnas usuküsimuste üle arutlejate omaga: kristlike väärtuste uurimine, sealt kaldumine sünkreetilise usu ja teosoofia suunas, otsingud etnilise omausundi alal ja kõigi teadmiste sulandumine kirjutistes. Usu-uuenduse teemaga alustanud K. Tõnissoni valikud erinesid teistest 20. sajandi alguse usulise tõe otsijatest oma lõpplahenduse poolest. Näiteks sel ajal, kui rahvaluulekogujana tuntud Hans Anton Schultz arendas fantaasiaküllast omamütoloogiat ja eelajalugu (Kikas 2006: 18 jj), arenes Karl Tõnisson budismi eestkõnelejaks ja propageerijaks. Tema kodumaine kirjategevus ühendab budismi sotsiaalriikliku utoopiaga kolme Balti riigi (autori kirjaviisis Eesti, Latvija, Lietuva) ühendamiseks Pan-Baltoonia riigiks, kus oli jäetud nišš ka etnilistele jumalatele. Tõnissoni tavatu ja skandaalne rõivastus, käitumine ja etteasted ajendasid linna- ja kuulujuttude teket. Ta ise on oma eluloo esitanud korduvalt luulevormis, kirjeldades suurte sõnadega usumuutust ja oma põhimõtteid (juutide usk võrdub vend Vahindra keelepruugis kristlusega):

\section{[---] kord oli aeg, kus hullustuses \\ Ma juute lora uskusin \\ Ja nõtru vendi - ilma rahvaid - \\ Küll valet kuulma kutsusin.}


Kord oli aeg, kus pööre tuli

Ja päästmine mu hingele,

Siis juudausu maha jätsin ja-

end andsin Buddha Dharmale.

Siis algasivad hirmuajad

mul tagakiusajatega.

Küll sõimasivad Eesti mehed

Mind oma ajalehtedega [---] (Vahindra 1928).

Tõnissoni sidemed Eestiga katkesid juba 1930. aastal, hilisemale tuntusele aitasid kaasa meediakirjutised, aga ka eestlaste külaskäigud Aasia budistlikesse keskustesse ja silmast silma kohtumised prohvetiga, mis moodustavad legendaarse osa imagost (vt lähemalt Talts 2003; Gerodnik 1973). Teated surmajärgsest imest Ranguunis ja tema arhaadiks-bodhisatvaks kuulutamisest andsid talle kodumaal erilise aupaiste.

Artiklis võrreldakse Karl Tõnissoni maailmalõpukuulutust teiste prohvetite tekstidega, samuti analüüsitakse, missugustes suhetes on rahvapärane maailmalõpuennete korpus prohvetipärimusega, missugused on ühisjooned ja erinevused. Lendleht on paigutatud K. Tõnissoni ajaliselt veidi hilisemal budistlikul ja samas rahvuslikpaganlikul maailmavaate teljel.

\section{Maailmalõpp rahvapärimuses}

Rahvapärane maailmalõpuennete mitmekesine süsteem toetub looduse ja ühiskonna empiirilistele vaatlustele, kuid seda mõjutavad omakorda õpetatud seisukohad. Meedia ja koolisüsteemi vahendusel on õpetatud seisukohtade mõjukus sajandist sajandisse kasvanud. Kahtleen Stewart ja Susan Harding väidavad 20. sajandi meedia kohta, et alati sündmuspaigal viibiv Ameerika meedia esitleb maailma sündmusi kui pidevat tautoloogilist kriisi (Stewart \& Harding 1999: 291) ja võimendab vastakaid seisukohti.

Enim tähelepanu on pälvinud ajast aega tavatud taevanähtused: varjutused või heleda komeedi ilmumine, aga ka halod, ringid või ristid päikese lähedal, samuti taeva ebatavaline värvus, asteroidid, komeedid ja nende mürgistest gaasidest koosnevad sabad, Maale langevad hiigelmeteoriidid, mis võivad põhjustada kõige elava hävingu. Samuti oma teljelt välja nihutatud maakera, planeetide järjestumise tekitatud korratus, mis nihutab maakera asukohta või ekvaatorit, viimasel sajandil ka sattumine hiigeltähe mõjupiirkonda, neeldumine Musta Auku, galaktika kokkukukkumine - need on vaid mõned 
näited pikast astronoomiliste nähtuste põhjustatud ja inimeste eluruumiga seotud murenarratiividest ja uskumuslikest motiividest. Mõnigi kord on oma silmadega nähtut seletatud Piibli kirjakohti abiks võttes, liites isiklikud kogemused ja tulevikuennustamise üheks tervikuks.

See jutustus on minu tädilt Triin Vakkumilt 1932. a.

Rahvas tõuseb rahva vastu, vend venna vastu. Toimuvad maavärisemised ja uputused. Inimesed ei tea, mis see tähendab, kellelt abi otsida.

[---] Järjekordselt külast (s.t meilt) kojuminekul sattus Triin ennenägematu nägemuse ohvriks. Põhjakaares oli tugev punetus, mis poole taevalaotust kattis. Punane kui veri. Ka mingid välgusähvatused ilustasid seda punast taevast. Tädi oli langenud põlvili ja palunud jumalat, sest ta kartis "viimast päeva”, s.o kus kõik on hävinenud, ainult inglid ja jumal üksinda elavad. Kas nad näevad inimeste moodi välja või loomakujutistega, seda tädi ei osanud seletada. Arvas, et küllap näevad välja inimestetaolistena. Vaene inimene oli põlvitanud mitu tundi, palvetanud härdasti, sest ta leidis end väga patuse olevat.

Uimane nutust ja suurtest palvetest tõusis, et kodu minna. Pöörates nägu hommiku poole ida suunas, märkas taevavõlvil pilvedest moodustatud veripunast risti. Nü̈̈d langes Triin põlvili, oodates koheselt maailma lõppu. Ei julgenud enam astuda. Hommikul leidis teda külainimene, kes aitas ta kodu.

Triin põdes mitu nädalat. Ei kuskil ei kurtnud valu ega vaeva, kuid ülesse voodist ei saanud.

Kui teda külastasin, vaatas mind võõra pilguga ja sosistas: "Sõda tuleb, suur sõda, sinna kistakse palju inimesi. Seal tapetakse palju ja sina lähed ka."

Esialgu ei uskunud mina ka teda, kuid 1938. aastal, kui teenisin sundaega Valkla suurtükiväe polügoonil, meenus see uuesti. 1938. a algas II maailmasõda. Kallaletung fašistide poolt Poolale. 1939. a Nõukogude sõjaväe sissemarss Eestisse. Fašistlik okupatsioon. Koonduslaagrid ja krematooriumid, ka minul tuli osa võtta Kaunase Stalag 336 vangina praegune $P$ fost.

Kas on maailmas nii tarka pead, kes ütleks, kui palju hukkus inimesi II maailmasõjas - niisugust ei leidu. Tädi Triinu ennustus läks täide. Peale suurt sõda, kui puutusin kokku viimast korda oma tädiga, mäletas ta seda veel, kuid keeldus oma nägemust uuesti jutustamast.

Küll aga oli tädi veendunud, et kõik see oli Jumala ettekuulutus, kuna maailma noored ja ka vanemad on taganenud usust, ei käi kirikus, ega 
palu jumalat. Veel palju, palju koledaid "asju” pidi meid ootama (RKM II 385, 524/7 < Pärnu l < Jämaja khk (1985)).

Hoopis rohkem on jäädvustatud usundilisi üldistusi, mida pole individualiseeritud:

Kui virmalised ôige suurelt vehklevad, kui ristid ja jooned taeva pääl on, ka kui taevas punane - tähendab sõda ehk suuri muudatusi (H, Kase, $100 \mathrm{a}<$ Halliste khk).

Näitetekstides kirjeldatu on seotud sümbolite ja märkidega, mis kuulutavad saabuvat hukatust ja lähenevaid muutusi. Kujutelm maailma tsüklilisest olemusest - ettenähtud aastate läbimise järel saabub häving, mille järel sünnib maailm uuena - on osa maailmalõpuuskumustest. Tsükli pikkus on määratletud kultuuriti erinevalt. Eestlaste pärimus kõneleb mõne tuhande aasta pikkusest maailmast. Seejuures viidatakse 19. sajandi üleskirjutustes, et "nii on Piiblis kirjas" või et "nii on ennustatud". Sajand hiljem eendub seos aastatuhandevahetuse kui lõpumärgiga.

Kate tuhandenda aasta sees, ku see täis saab, siis tuleb maailma lõpp. Ega ta kohe ei tule, võib-olla läheb aasta vai paar aega (RKM II 461, 321 (8) < Võnnu khk (1986)).

Tavauskumuste üks funktsioone näib olevat kontrollida inimühiskonna moraali, ühendades lõpuajad maailma ja loodu allakäiguga. Rahvapärase loogika kohaselt ammendub aja jooksul loodu elujõud ja mandumise kõrgpunktis hukkaläinu hävib või hävitatakse. Hävingu põhjuseks võib olla inimeste ja kogu elava looduse füüsiline ja moraalne taandarenemine (rahvapärased seletused: kanad ei suuda muneda, inimesed on suure peaga, kuid väikeste käte ja jalgadega; kanamuna tuleb kanda kahe mehe vahel, sest inimsugu on nii nõrgaks jäänud, et üksinda mees muna kanda ei suuda). Suure pea ja nõdra füüsisega inimsoo ees puhkes hirmulaine uuesti personaalarvutite ja hiljem interneti meelelahutuslike võimaluste ja suhtlemisvõrgustike levimine. Muretsejate hulgas oli nii lihtkodanikke kui ka haritlasi.

Euroopa kultuuriruumi sajandeid erutanud Nostradamuse (1503-1566) prohvetisõnumid ühendati aastaga 2000. Maailmalõpu täpne ajastus elavdas sajandi teisel poolel vaidlusi skeptikute ja uskujate vahel ning sundis otsima tehnoloogiast, loodusest ja ühiskonnast kriisimärke. Globaalse haardega sõjad, majanduslangused, ja meedia info võimendasid ohumärke ja avasid uusi tähendusi. Juba aastakümned enne millenniumi saabumist pakuti komeetide ilmumise (Kõiva 2007) ja loodusmärkide põhjal konkreetseid maailmalõpu kuupäevi. Vaevalt jõudis üks tähtaeg mööduda, kui esile kerkis uus. Armageddon, 
samuti millenniumiga kaasnev ajastute vahetumine ehk nn valguseajastu saabumine koos valgusolendite maailma algusega olid sagedased jututeemad. Hävingu põhjustajaks peeti globaalset soojenemist - näiteks levisid lood, kuidas Tallinn upub aastal 2000 jäämägede sulamisvette või ootamatu katastroofiga vallandunud tulvavetesse. Kardeti globaalset reostumist või jääaja saabumist. Levisid ka kuuldused uuest ravimatust haigusest, mis saab alguse Aafrikast nagu aids ja tapab valikuta hoolimata soost, vanusest ja rahvusest ning puhastab inimestest enamiku maailma piirkondadest. Erilise hävingu osaliseks pidid langema suurlinnad, kus on kõrge asukate kontsentratsioon. Kardeti ka globaalset tuumasõda, mille järel elavate olenditena jääksid ellu vaid ämblikud ja rotid ning loodetavasti mõned inimesed kusagil Lõunamere saartel. Eesti iseseisvumine vallandas hoiatusjutud suurest näljahädast ja ühtaegu erilisest jumaliku viha alusest paigast, millele on määratud lähiajal mingi suure katastroofi käigus täielikult hävida.

Müüdipõhine mõtlemine ühendab maailmalõpu müütiliste katastroofidega. Maailma(de)/jumalate sõja käigus hävib kogu elu ja hukkumine vallandub karistusena jumalike olendite rüvedate tegude eest pärast eksimist legitiimsete normide vastu. Vanema Edda traagiline jumalate ja inimeste hukkumine leidis aset reeturlike ja alatute tegude tulemusena. Varauusajast levinud arvamused, et maailma püsimist ohustab inimeste patustamine, jumalariigi seaduste rikkumine ja uskmatus, on selgesti tajutavad veel osas 19. sajandi lõpu kirjapanekutes. Alles 20. sajandil hakkab peamise põhjuse - eksimused jumala seatud reeglite vastu, millele järgneb karistuseks jumala ja looduse koosmõjuna saabuv maailmalõpp - kõrval laienema uskumustik, mis toob esile lõpu kui inimese mõtlematu isepäise käitumise tulemuse. Sellised uskumusnarratiivid väljendavad hirme ja hoiatusmotiive liigse tarbimise, looduse reostamise, samuti katsete ees kloonida elusloodust ja inimesi, muundada geneetiliselt vilju ja loomi. Neid peeti sama ohtlikeks tegudeks kui paratamatult lähemas tulevikus vallanduvat võimsate massihävitusrelvadega III maailmasõda, kõige elava lõppvaatust.

Inimtegevus, tehnika või laiemalt tehnoloogia areng põhjustas vanade motiivide uuenemise, kuhu kuulub masinate mäss oma loojate vastu. 20. sajandil kerkis igaühe moraalsest käitumisest tuleneva kollektiivse negatiivse summa ja vastutuse problemaatika kõrvale üldisem motiivistik inimesest kui ohtlikust loojast, oma mõistuse ja loominguga planeedi saatust mõjutavast või seda hukutavast olendist. Uskumusmotiivid räägivad homo sapiensi rumaluse, kergluse, mängulusti vm tõttu vallanduvast hävingust. Masinate mässust arenesid hirmulood masinate ootamatust arenemisest inimesega võrdsele tasemele, masinates kogemata tekkivast hälbest või programmeerimisveast. Alles kümnekonna aasta eest, enne aastat 2000 levis Ameerika Ühendriikides Y2K 
paanika. Ametiasutused soovitasid varuda koju toitu, küünlaid ja sularaha ning püsida kodudes, et vältida millenniumi vahetusel programmeerimishäire tõttu töötamast lakkavate kodu-, panga- ja tööstusmasinatest põhjustatud kaost. Online-religiooni uurija Brenda E. Brasheri arvates kujundasid prohvetlikud ennustused esialgselt külmalt uudisesse suhtuvast publikust arvutivastases paanikas osalejad. Ennustused ja küberpaanika vastasid äärmuskristlaste ootustele (Brasher 2004: $56 \mathrm{jj}$ ), kuid üksnes kaasaegsed isiklikud meenutused lubavad meil näha prohvetisõnumite mõju inimeste käitumisele.

Viimasel kümnendil on "viimsepäeva"prohvetid taas talveunest ärganud. Aastal 1997 kolisid mu vanemad ära San Fransico lahe piirkonnast, et pääseda suurest maavärinast, mida prohveteeriti Lõuna-Kaliforniale. See maavärin pidi hävitama Hollywoodi selle ebamoraalse saastamise ja San Fransisco homoseksuaalse perverssuse tõttu. Sama prohvetlik sõna kuulutas, et Põhja Kaliforniast saab rannikuala.

Minu isa ja ema kolisid lahe äärest Nevadasse Tahoe järve lähedusse, et leida prohvetlik "lennukeeluala". Samal ajal kui minu vanemad uues kohas sisse elasid, hakkasid mitmed prohvetid kuulutama tulevast rahvusvahelist näljahäda. See sai üle maailma tuntuks kui "Y2K" palavik. Me pidime langema kohtumõistmise alla seetõttu, et olime teinud oma intellektist jumala. See oli täiuslik "Jumala plaan”. Selle plaani järgi oli inimese rumaluseks pime lootus enda nutikusse. Tundus, et Isand oli pimestanud kôikide arvutifriikide silmad, et nad ei avastaks seda, et varsti nälgib kogu maailm ühe numbri puudumise tõttu. Milline lõpp! Pidid algama mässud tänavatel ja inimesed pidid leidma end silmitsi kiusatusega kannibaliseerida oma naabreid ja lapsi. Järgmisena pidid langema ärid ja valitsused. Mõned kuulutasid isegi, et see algatab nn "Kõikide Sõdade Ema". Inimesed ostsid massiliselt generaatoreid ja relvi, et kaitsta "Isanda Nimel" oma toidulaudu. Pole vaja mainida, et kõik need ettevalmistused osutusid mõttetuks, aga minu vanemad sõidavad siiani mereranda jõudmiseks tunde (Valloton 2007).

Modifitseerus veel üks vana motiiv - maailma hukutava (inim)olendi või messiase sünd, kellena peeti silmas eeskätt tundmatus maakohas kasvavat maailma saatust muutvat isikut, kuid kes omandas uutes oludes mõne suurriigi konkreetse valitseja näo ja nime. Ebatavaline sünnimärk - metsalise sümbol - Mihhail Gorbatšovi näol koos Nõukogude Liidu poliitikat ja pidurdunud majandust raputanud reformidega panid ennustajad ja lihtrahva nägema temas maailma hävitava metsalise kehastust. Nõukogude Liidu lagunemisega seotud muutuste pelu väljenduseks oli uusima aja prohvetite ennustus sümboolsest õunakärust, mille Gorbatšov kummuli keerab, põhjustades hukatuse. 
Huvitavate poliitiliste fantaasiate hulka kuuluvad hirmud, et kusagil laboratooriumis säilitatakse Stalini või Lenini pead, mille teadlased ühendavad uue kehaga (arvutitega) ning taasloovad niimoodi maailma valitseva ja seda hävitava ülikurjuse. See motiivistik, nagu osa eespool loetletud tehnoloogiafoobiatest, on arendus hirmust teaduse kui destruktureeriva jõu ees.

Uskumusjuttude uued üliolendid on tulnukad, ufod, kõrgem ja vaenulik tsivilisatsioon, kelle missioon on pärimusjuttude põhjal inimestega katsetada, neid jälgida ja hinnata, kaugemas plaanis aga meie maailm hävitada (vrd Ameerika vastavat ainestikku Stewart \& Harding 1999: 296 jj).

Kõigi loetletud lõpuennete ühine tunnus on tähtaegade paikapanemine kas kindla kuupäeva ja aastaga või selle määramine ebamäärasema lähitulevikuga. Just 20. sajand oli rikas konkreetsete maailmalõpukuupäevade ja -aastate nimetamise poolest (komeetidega seotud loetelu nt Kõiva 2007: 181). Retrospektiivselt on neid hiljem ühendatud konkreetsete sõdade algusaegade ja muude pöördeliste sündmustega:

Ma olin kuolilaps viel, siis ühel päeval pidi päike madalamalt käima. Vaatasin päikest ja tõesti oli madalamal. Sie oli südatalve ajal. Sie oli kolmekümnendatel aastatel, üks päev, mille kohta rahvas rääkis enne, et nüid tuleb maailmalõpp. Et ega sie muidu ei ole, sie päikese asi (RKM II 371, 699/700 (11) < Viru-Jaagupi khk).

Maailmalõpuended peegeldavad ühiskondlikke, kultuurilisi ja tehnoloogilisi muutusi, mis kajastuvad ka rahvaluuleteadetes. Viimsepäevahirmud integreerivad üha uusi seletusviise ja hävingupõhjusi. Esitatud mittetäielik loend iseloomustab eelmise sajandi teisenenud kultuurilis-majanduslikke olusid ning toob esile teadlaste uuemate seletuste mõju rahvapärasele uskumustikule. Astronoomia, füüsika, geneetika jt teaduste avastused on täiendanud oluliselt ka maailmalõpumärkide loetelu. Nendes esinevad sümbolid, märgid ja seletused toovad ajastu kontekstist esile tüüpilised, stereotüüpsed, korduvad sõnumid ja uued originaalsed ended.

Ka teatud kindla ideoloogia tootmine ja sotsiaalsete normide paika seadmine näib olevat maailmalõpuennete ülesanne. Ended on tihedalt seotud sündmustega, mis hirmutavad sotsiaalseid rühmi - olgu selleks ootamatud muutused seadustikus või aimatavad reformid. Iga suurem muutus majanduses või sugupoolte käitumisstrateegiates on vallandanud ka maailmalõpuended. Nii ennustati eestlastele 20. sajandi alguses maailmalõppu, kui naised hakkavad kandma lühikesi juukseid ja miniseelikuid. 


\section{Prohvetite ettekuulutused}

Eriline koht maailmalõpuennustuste jadas on prohvetite nõuannetel ja maailmalõpukuulutustel. Andes edasi invariantse sõnumi ja kuulutades avalikult jumalikku tõde, mõjutasid prohvetid rahvapärast uskumuste süsteemi. Piibliprohvetid (Heseekiel, Jeremia, Habakuk, Jesaja jt) tegutsesid kriisiolukordades. Jumalasõna omapäraselt ja isiklikult tõlgendanud ja seda koos isiklike ilmutuste ja sõnumitega vahendanud rahvaprohvetid kerkisid Eestiski esile kriisi- või usuliste uuenduste aegadel. Erineva tausta ja püüdlustega iseõppijatest pühakirja seletajate ühisomadus oli isiklik karisma, mis kombineerus spontaanse käitumisega.

Prohvetipärimus on õpetlashuvi keskmes olnud korduvalt, pakkudes huvi harukordse võimaluse tõttu saada teateid rahva usutunde erijoontest ja prohvetite isiksusest. Matthias Johann Eisen on asetanud Järve (Järva) Jaani, rahvaluulearhiivis paljude tekstidega esindatud 19. sajandi prohveti, varasemate mitte-eestlastest prohvetite diskursusse (Eisen 1921). Järgnevad uurijad (Rudolf Põldmäe, Olav Sild, Uku Masing, Kristi Salve) on käsitlenud üksikprohvetite päritolu, saatust, ilmutusi ja nende mõju lähemale usurühmale (Põldmäe 1935, 1937; Sild 1929, 1935; Masing 1935; Salve 1998, 2000). Vaatluse all on olnud ennekõike usuelu elavdanud 18. ja 19. sajandi vennastekoguduse äratusliikumise usujuhid ja prohvetid. 19. sajandi algusse jääb ulatuslikum prohvetiliikumine - nn taevakäijad -, tollaste prohvetite seas oli naisi ja teismelisi tütarlapsi (Põldmäe 1935; Sild 1935; Kalkun 2006). 19. sajandi suurkujude hulka kuulusid prohvet Maltsvet (Masing 1993 [1934-1935]), Habakuk II, Vastseliina aladelt pärit Kordo (Salve 2000), Järve Jaan (Eisen 1921) jt. Rudolf Põldmäe hinnangul on näiteks taevakäijate liikumises rohkesti üldinimlikke jooni, mis esinevad vastavate olukordade saabudes igal rahval. Ta hindab kokkuvõttes prohvetiliikumist kõrgelt:

Meie pärisorjastatud talupoja erilistest dispositsioonidest tingituna aga kujunes sellest esialgselt puhtusulisest liikumisest ka majanduslik-sotsiaalne sihitaotlemine, seega teataval määral ka ette valmistades pärastist poliitilist ja kultuurilist ärkamisaega, küpsetades nõnda omamoodi mehi kui naisi ühisaktsioonideks oma õiguste kaitsmisel ja õpetades kokkuhoidmist raskemail pöördepunktidel (Põldmäe 1935: 176-177).

Kui vaadata prohvetite kuulutamist, koguduseliikmeile esitatud usulisi ja elulaadi nõudeid, on need laiema sotsiaalse kriitika või ideoloogia osa. Näiteks 18. sajandi prohvet Tallima Paap taotles sotsiaalset võrdsust (mõisnikud on saatanad, kellelt tuleks mõisad ära võtta ja nende varad inimeste vahel venna- 
likult ära jagada), samal ajal kutsus ta üles loobuma uhkeldavatest maistest asjadest ja ehetest ning järgima askeetlikku eluviisi. Samasugused nõuded korduvad 19. sajandi prohvetite seisukohtades. Kriitika alla langenud ühiskonnakihid on püüdnud sõnumeid summutada järelevalve, manitsuste, muude karistuste ja vaimse tervise ekspertiiside abil.

Järve Jaani ja Vastseliinast pärit Orava prohveti Kordo ennustusi võrreldes ilmnevad suured sarnasused. Individualiseeritud pikemate narratiivide vahendusel joonistuvad välja igapäevaelu puudutavad ettekuulutused. Mõned lugudest on üldinimliku sõnumi tõttu mugandatuna levinud pikemat aega suust suhu.

\section{Järve Jaan}

* Tehnilised uuendused: rong (hobuste asemel hakkavad kord suuri koormaid vedama tuli ja vesi), telegraaf; kirikus pill hüüab ja kogudus vaikib.

* Olme- ja sotsiaalsed muutused: rõivastus (saapad - meeste jalatallad kliisterdatakse ära), soode kuivendamine, kalanappus, meres sõidavad kadakamarjakoormad.

* Üksikisikute saatus: puudutab Pärnu- ja vana Läänemaa inimeste või hoonete saatust.

* Poliitilised muutused: Venemaa kuivab kokku ja on kord hobuserauakujuline. Kuulutas Rootsi mõõga võitu. Tuhandeaastane rahuriik ei saa enne tulla, kui Vene tsaar Kremli aknast tsaaririigi piirid ära näeb. Ennustuse järgi tulevad parunid korraks tagasi, et siis varsti jäädavalt lahkuda. Türklased jõuavad kord Kirbla kirikuni.

* Usuküsimused ja maailmalõpp: Rumba jõe silla valmimisele järgneb maailmalõpp või suur sõda. (1939. aastal Rumba sild valmis, nädal hiljem tungisid sakslased Poolasse, algas maailmasõda.)

\section{Kordo}

* Tehnilised uuendused: raudtee, lennuk, auto, telegraaf (tuleb aeg, kus ilma mööda saab käima otsekui inimese vaim - nii ruttu, ja talitab kõik asjad; raudruun saab sõitma, joob vett ja sööb tuld).

* Olme- ja sotsiaalsed muutused: raha hakatakse vakaga mõõtma, aga leivast saab suur puudus olema; ametnikke palju; mõisate häving, mõisamaad jagatakse; eestlastel on oma maa, kuid väga väikesed maatükid, igaühel piirid märgitud.

* Usuküsimused ja maailmalõpp: usk kaob ära, nii et ei minda enam kirikusse ja kurat hakkab jalgsi maad mööda käima; “Tuleb aeg suurte sõdadega 
ja rahvas saab ära hävitatud, nii et Riiast Pihkvani ei kuule kuke laulu ega koera haukumist. Inimesed, kes järel jäävad, saavad otsima teiste jälgi, kuid ei leia. Selline aeg tuleb, et kui inimene sattub teise inimese jälgedele, hakkab nutma"; inimsugu muutub niivõrd nõrgaks, et ei jõuta enam kanamuna üle terava otsa pöörata.

Rudolf Põldmäe kirjeldatud taevakäijate prohvetiseeringutest leiame mitmeid maailmalõpumotiive, mis on hiljem rahvaluulekorpusesse kogutud ja millest võib järeldada mõlema pärimusosa vastastikuseid mõjutusi:

Jumal saatvat nuhtluseks valged rotid inimeste kallale, elavalt nende liha sööma. Muud nuhtlused tulevat, kui rahvas meelt ei paranda ega Jumala poole ei pöördu. Tema kõnelused viisid rahva seevõrra segadusse, et mõisarahvas pidas tarvilikuks hingede-rahustamiseks koha peale ehitada palvemaja (Põldmäe 1935: 168).

Teise ennustuse järgi kuulutanud Viljandi taevakäijad, et enne viimast päeva hakkavat raud raua vastu kõnelema - see olevat siis telegraaf. Kui naised hakkavat paljaste peadega käima, - enne see oli võimatu eksimus maksva kombe vastu-, ja kui juukseid hakatavat kuklasse kokku mässima (omaaegne mood!), siis olevat jälle viimnepäev lähedal. Enne seda tulevat aga veel suur ärkamine, millest paljud õndsaks saavad (Põldmäe 1935: 172).

Uku Masing arvab, et Juhan Leinbergi ehk prohvet Maltsveti liikumine oli alguses "hulga eshatoloogilisemalt ekstsentriline kui hiljem. Maltsvet kuulutas kõigepealt maailma lõppu ja kuna see oli lähedal, nõudis, et inimesed end parandaksid" (Masing 1935). Ka Maltsveti kuulutustes on usureformide, konkreetsete käitumis- ja elukondlike normide kõrval poliitilised ja sotsiaalsed nõudmised, kriitika ja skeptitsism Vene riigi suhtes. Dispositsioon ametliku kirikuga (Maltsvetil vennastekogudusega) sarnaneb varasemate prohvetite sättumustega, samuti ühendavad kuulutused isikliku ja kollektiivse ajaloo, millega on rikastatud õige usulise käitumise väärtustamisega.

Maailmalõpu aja on Juhan Leinberg korduvalt paika pannud. Esmalt kuulutas seda komeedi ilmumine. Selle ilmumisajaga eksis ta 1858. aastal kogemata. Valge Laeva ja läheneva hukatuse saabumise kohta on ta ise ja tema abiprohvetid andnud kogudusele 3. veebruarist 1860 kuni 24. maini 1861 kokku kaksteist tähtaega. See seik osutab, kui vankumatult pidid jüngrid ja järgijad uskuma oma prohvetisse, et vaatamata mitte millegi juhtumisele ja üha uutele tähtaegadele prohveti sõnumit siiski usaldati. Matthias Johann Eisen osutab erinevate rahvajuttude põhjal pikemat aega nurjunud imetegudele ja sõnumitele, mis poolehoidjate usku siiski ei hävitanud: 
Jutlust pidades ja meeleparandust nõudes leidis ta palju poolehoidjaid. Neid lubas ta Samariasse viia kuivalt läbi mere. Jutlustamise kõrval kuulutas ta agaralt ette: "1862 lähevad kõik hukka, kes mu järele ei käi. Eestimaal tuleb nii suur vere äravalamine, et veri kedreluuni ulatab." Teise korra ennustas ta jälle: "Tuleval kevadel viib Püha Vaim kõik äravalitud pilvel ära." Jälle teise korra hü̈̈dis ta jõele: "Seisata, et me kuivalt läbi läheme!” Kui ta ettekuulutused täide ei läinud, lükkas ta sü̈̈ rahva umbusu peale. Hiljemini lubas ta järelkäijaid Lasnamäelt valge laevaga Kaananisse viia. Ilmumata laeva asemel viis Maltsvet järelkäijaid maad mööda Krimmi (Eisen 1921).

Uku Masing on seisukohal, et piiblit hästi tundnud Maltsvetile oli maailma lõpp siiski mööduv katastroof ja pigem kitsaste aegade enne. Ta viitab seigale, et väljarändajad on jätnud lastele korralduse tulla Krimmi järele, sest "kolme aastaga pidavat Eestimaa muutuma tühjaks ja siis tulevat tuli ja mõõk ning ots maal". Muude andmete järgi tulevat sõda, mis tapab kõik inimesed, kes pole maltsvetlased (Masing 1993: 153). Viimased kuulutused sarnanevad rohkem kui sada aastat hiljem, 1990. aastatel prognoositud suure näljahäda ja hävinguga, millest oli eespool juttu, samuti Elu Sõna kiriku kuulutustega.

Järve Jaani maailmalõpuended on seotud muutustega kõige lähemas ümbruses, samas ajaline distants ennustatud sündmusega on ebamäärasem: külade teistkordne põlemine (nt Lavassaare küla), Vee kõrtsi esine maa vajub ära, Kuresoo Alttõnisel saab Ott peremeheks, Kõima vesiveski paisualune maa tehakse põlluks, Naartsi hiis kuivab ära ja Naartsi küla laotatakse, Rumma jõele ehitatakse sild jne.

Osa tema maailmalõpuennetest on seotud lähenevate sotsiaalsete ja majanduslike muutustega: kui Pereküla linnaks muutub ehk kui majadele korstnad ehitatakse ja akendele kardinad ette pannakse, kui nuumhärjad vedama pannakse, kui rahvas poes käima hakkab, tuleb varsti viimne päev.

Mitmed prohveti pakutud tähtajad on sedavõrd stereotüüpsed ja üldistatud, et võimaldavad neid mugandada erinevate ajalooliste oludega: kui Mihkli kirikus härg mürama hakkab või Kirbla kirikus Türgi täkud hakkavad hirnuma, ei ole viimne päev enam kaugel. Sellised sõnumid sobitati 20 . sajandil nõukogude võimu kirikuvastase poliitikaga, selgitades nii tühjenenud pühakodasid ja sekulariseeruvat ühiskonda. Türklastega seotud seletused on omandanud uue tähenduse alles pärast Euroopa Liiduga ühinemist ja varjutavad varasemad Krimmi sõja ja Teise maailmasõja järgse rahvaste rändamisega seotud tõlgendused. Paljud Järve Jaani ennustused jätavad tänaseni avara seletamisvabaduse tehnoloogiliste saavutuste ja keskkonna muutuste osas (kui raudvits üle maa tõmmatakse, tuleb varsti viimne päev). 
Ka 20. sajandi oluliste prohvetite Saaremaa Seiu ja Karl Reitsi tegevuses eenduvad usuküsimuste ja ametliku kiriku kriitika kõrval sotsiaalne (alamrahva karm kohtlemine, mõisa ja kiriku vale elulaad) ja üldine poliitiline kriitika ning üleskutsed meeleparandusele tuhandeaastase rahuriigi saabumise eel.

\section{Meie maakera viimased minutid ja Karl Tõnissoni usulis-filosoofilised arengud}

Kuhu paigutada eespool loetletud korpuse suhtes Karl Tõnissoni, hüüdnimedega Vend Vahindra ja Paljasjalgne Tõnisson, maailmalõppu ennustav piibliuurimuslik lendleht?

Alates 15. sajandi keskpaigast levitati poliitiliste vaadete meediumina, hiljem ärireklaamidena kirikute juures, laatadel ja mujal rahvarohketes kohtades väikese tasu eest lendlehtesid. 18. sajandil nende sisu avardus, kuid vormistuslikult oli jätkuvalt tähtis illustreeriv visuaalne külg, mis hõlmas kuni kolmandiku kogu trükise pinnast. Sellise kujundusega lehtesid kasutati kaunistuselementidena seintel isegi kirjaoskamatutes kodudes. Hinnatud olid võõrapäraseid metsloomi ja maastikke, tundmatuid olendeid ja monstrumeid kujutavad lendlehed. Ühel vanematest illustreeritud lendlehtedest, Sebastian Branti kujundatud Ensisheini piksekivil (1492) on pilt meteooride langemist kui õnnetuse hoiatusest. Rudolf Põldmäe (1935: 153) andmetel olid näiteks 19. sajandi lõpul rahvaraamatukeste juurde kuuluvad värvipildid kohtumõistmisest ja viimsestpäevast populaarsed talutarede kaunistuselemendid, üks neist on esitatud käesoleva artikli illustratsioonina ( $1 \mathrm{k} 114$ ).

Lendlehtedes kirjeldati veel sensatsioonilisi uudiseid ja räägiti imedest, ennustustest, hingehoiust, edastati poliitilisi ja militaarseid uudiseid. Reformatsiooniajast alates kujunes lendlehtedest oluline usuliste vaadete levitamise vahend. Tuhanded eriteemalised tasuta levitatud lendlehed olid 20. sajandil oluline vahend näiteks Saksamaal juutide kohta valeinformatsiooni levitamiseks, neid kasutati inimeste hirmutamiseks, jätkuvalt poliitiliseks ja militaarseks propagandaks ja üleskutseteks, ehkki päriselt ei kadunud tervisevõtetest teavitamine jm teemad.

Meie maakera viimased minutid (Tennison 1907) jääb autori kui otsiva luterlase - kes ta päritolu poolest ongi - perioodi ja on koherentne seisundiga, kus ta alles otsib uut väljendusviisi ja ideoloogiat maailma seletamiseks. Autoritutvustus piibli- ja ajaloouurijana ning viited Ilmutuse, Taanieli, Matteuse, Jeremija ja Heesekieli raamatu kirjakohtadele osutavad pühakirja valdami- 
sele, kogu tekst aga oskusele teatmeteoste, aimekirjanduse ja ajaloofaktidega opereerides oma sõnumit edastada. Lendleht sisaldab viis illustratsiooni: kuningas Nebukadnetsari unes nähtud kuju, mille tähenduse selgitas talle prohvet Taaniel, kaks pilti pimedast päevast Uus-Inglismaal 19. mail 1780, tähesadu 13. novembril 1833 ja pilt allkirjaga "Meie maakera ärahävitamine, mis varsti saab sündima" viitega kirjakohale Matt 24, 27. Päises asuva sümbolkuju pildi kõrval paiknevad kaks puulõiget kõrvuti lendlehe esimesel ja kaks kõrvuti teisel leheküljel.

Lendleht algab maailma allakäigu seletamisega, kasutades Taanieli raamatu kirjakohti ja Nebukadnetsari unes nähtud kuju. Järgime tema mõttekäiku, esitades faktoloogia muutmatuna. Kuju iga osa on viidud vastavusse kindla poliitilis-ajaloolise riiklusega. Kullast pea kujutab Babüloonia kuningriiki (677-538 eKr), hõbedast rind ja käevarred Pärsia (538-331 eKr) ilmariiki, vasest kõht ja puusad Kreeka riiki (331-161 eKr) - selle asutajaks nimetab ta Aleksander Suurt, kes 12 aasta jooksul terve Aasia ja teised sel ajal tuntud maad vallutas -, rauast sääred kujutavad ilmariik Roomat (161 eKr - 483 pKr): üks säär on paganlik ja teine paavsti Rooma - ühe varisedes tõusis rusudest teine. Tõnisson kirjutab: "Rooma paavst oli see vägev võimumees (piiblis nimetatakse teda metsaliseks ja valekristuseks), kelle ees kõige vägevamad valitsejad värisesivad." Kuju kümme varvast on rauast ja osalt sauest, need 10 riiki on (tema kirjaviisis): hunnid, idagootlased, läänegootlased, frankid, vandalid, suevlased, burgundlased, herilased, angelsaksid ja lombardid, kellest sündisid Itaalia, Portugaalia, Hispaania, Saksamaa, Prantsusmaa, Inglismaa, Austria jne.

K. Tõnisson jätkab piibli kirjakohaga, kus Nebukadnetsar näeb kivi kukkuvat kuju jalgadele (Taanieli 34-35), mille järel kogu kuju pekstakse puruks "ja tuul viis neid ära ja neil ei leitud ühtegi paika". Tõnissoni arvates kujutab kivi endast Kristuse igavest riiki, mis meie päevil kõik praegused riigid ära lõpetab, aga ise jääb igavesti kestma.

Tema järgneva arutluskäigu kohaselt elavad inimesed sel ajal kuju "varvastes", väikeste riikide ajal, ja tema arvates ei tule ühtegi ilmariiki enam, ka üksikud riigid ei saa endid ühendada, vaid nad jäävad üksikuteks riikideks kuni lõpuni.

Ajaliselt distantsilt on tema 1907. aasta veendumus, et suurte ühendriikide aeg on möödas, humoristlik. Eriti paigutades selle tema enda hilisema isikliku poliitilise utoopia Pan-Baltoonia (mida ta asus kavandama 1920. aastatel) taustale või meenutades, et kümmekonna aasta pärast hakkas kerkima Nõukogude Liit - kuuendik kogu planeedist, nagu hiigelriik tavatses ennast tituleerida -, Suur-Saksamaa jm uued ühendused. 
Illustratsioon 2. Unes nähtud kuju K. Tõnissoni lendlehes Meie maakera viimased minutid.

K. Tõnissoni arutlus jagab riigid vaesteks ja rikasteks vastavalt sümbolkuju varvaste materjalile: vägevad on Inglismaa ja Põhja-Ameerika ning nõrgad Šveits, Belgia jm savivarvaste riigid. Nagu majanduslikud ennustused ikka, ei ole seegi ajale vastu pidanud.

Järgnevas arutluses jõuab ta viimaste minutite ettekuulutamiseni. "Me elame üsna lõpu lähedal ja Piibli abil võib seda selgeks teha, et praegune inimesesugu viimane on. Sellest paar näitust," kirjutab ta, viidates, et Mt 24-s kõneles Jeesus maailma lõpu üle ja nimetas kolme märki: 1) maavärisemine, 2) päikese pimenemine, 3) tähesadu. Ta jätkab: "Seesinatse põlve rahvas ei lõpe mitte ära, kuni kõik saab sündinud.” K. Tõnisson tutvustab kolme lõpuaegade märki. Esimene oli maavärisemine Lissaboni linnas aastal 1795 ja teine oli pime päev Põhja-Ameerikas ja mujal 19. mail 1780. Huvitavalt toob ta siin esile isiku, kelle loomet kasutame tänagi igapäevase abivahendina - pimeda päeva informatsiooni vahendab ta Noah Websteri töö abil: “[---] oma ilmakuulsas sõnaraamatus, pealkirja all kuulsate nimede juhataja, järgmist: "Pime päev oli 19. mail 1780 - nõnda nimetatud sellepärast, et sel päeval üks tähelepanemise väärt pimedus valitses, mis ennast kogu üle Uus-Inglismaa laotas. Mõnes kohas oli pimedus nii suur, et mitu tundi isegi koguni lihtsat trükikirja väljas lugeda ei võinud."' Kolmandaks märgiks peab K. Tõnisson viimase paari sajandi suurimat meteooritormi 13. novembril 1833. Siingi on tal kinnitus teadlaste sulest: "Professor Almstead kirjutab selle üle: “Tähesadu aastal 1833 oli suur küllalt, et ühe tähtsa osa maa üle ulatada. Ta laotas ennast Ida-Atlandi ookeanist kuni Vaikse ilmamereni kaugele õhtu poole ja Lõuna-Amerika põhja rannast kuni Britannia asumaade määramata piirideni põhjas. Igalpool oli ta nähtav ja pea igal pool oli ühesugune vaatepilt. Seda sündmust ei või kauem maapealseks nähtuseks arvata, vaid peab üheks taevaliseks pidama."” 
K. Tõnissoni edasine arutluskäik tugineb ühtaegu piiblile ja seigale, et kuna viimasest märgist - tähesajust - on 75 aastat möödas, siis

[---] tuleme sellele kindlale ja kõikumata, aga ka kohutavale otsusele: inimesed, kes 80 aastat vanad, saavad oma elupäevil Jeesuse ilmumist pilve sees nägema, - jah, meie, kes meie praegu maa peal elame, saame kõiki neid hirmsaid aegu läbi elama, mis varsti oodata on. Kohutav saatus ootab meid kõiki. Inimesed saavad viimseni maa pealt ära kaotatud, maha tapetud ja nende surnukehad, mis ühest maa otsast teiseni maad katavad (vaata Je. 25, 33), saavad lindudele taeva all roaks antud (vaata Esek. 39, 17-29 ja Ilm. 17, 17-21). Ainult üks väikene salk inimesi saavad ära peasema, nimelt need, kellede nimed elu raamatus taevas üleskirjutatud seisavad, kes metsalist ega selle kuju ei kummarda, vaid kes Jumala käsusõna peavad ja Jeesuse usku on (Ilm. 14, 12: 22, 14). Ainus peasemistee on see, mis meile piiblis ette on näidatud. Võtku iga üks vaevaks piiblit hoolega uurida ja kõiki selle ette kirjutusi ja käskusid täita. Seal on igavesed Jumala teadmised ja käsud, kes neid peavad, need saavad igavesse elusse - uue maa peale, kuna nende põlgajad selle planeediga tükis ära hävitatakse.

Ja ta lõpetab oma lühikese arutelu hüüdega: "Valigu nüüd igaüks omale kas igavest elu ehk surma!”

Prohvetikuulutusel on selge ja loogiline ülesehitus ning see toetub võrdväärselt piiblitundmisele ja õpetatud meeste autoriteedile. Teadus ja õpetlaste trükisõna on piibliga samaväärselt usaldatav allikas, objektiivne ja autoriteetne kinnitus toimunule. See on uus joon prohvetisõnumites, nagu ka eritasemeliste tsitaatide kasutamine oma sõnumi kinnitamiseks ja edastamiseks. Sümboolsed märgid on ajalooliselt toimunud olulised sündmused, nende aset leidmises pole põhjust kahelda. Ehkki kolmest juhtumist kaks on olnud nähtavad üksnes Ameerikas, on nad kunsti ja trükiste vahendusel palju laiemalt tuntud. Üleskutsed piibli uurimisele ja õigele elule esitatakse alles lendlehe lõpus. Kogu prohvetiseering on läbimõeldud arutlus. See ei ole konkreetse ilmutuse teel saadud pildistik ega ülemeelse kogemuse ümberjutustus. Ilmutuse saamise paik on sümboolne, jääb avamata, seda ei kanta kohalikule maastikule. Autori eesmärk on kutsuda viimsepäeva eel meeleparandusele ja piibliuurimisele, kuid see on rüütatud aastaarvude, kuupäevade ja tsitaatidega kinnitatud arutlusse. Samas ei ole ilmalõpu uskumine midagi lõplikku ega füüsilist, see on raamatutekstide vahendatud teadmine.

Konkreetne lendleht oma argumentatsiooniga vastab ratsionaalselt meelestatud 19. sajandi normidele. Ajaloolised faktid on osavasti valitud ja mõju- 
sad. Vähemalt 1833. aasta tähesadu leidis laialt folklooris kajastamist ja oli mitmete omaaegsete eelarvamuste alus (nt Kronk 2010; Space Science 1999).

Trükitud lendlehe mõju kogukonnale on raske hinnata. See oli üks uue aastatuhande alguse tõlgendustest. Karl Tõnissoni viisid usulised otsingud kristlike kirjakohtade ja usukuulutamise juurest edasi eestlaste vana omausundit otsima, sellest kirjutama ja seda oma teadmiste pinnalt looma. Kahtlemata olid tema teadmised eestlaste usundist napid ja pinnapealsed, toetatud pigem rahvusliku ärkamisaja meedia- ja õpetlaste populaarsetest tekstidest ning oma fantaasiast, kui sügavamast rahvaluule tundmisest. Tema kasvukohas Umbusis, suure rabamassiivi läheduses, polnud jõukaid põlistalusid ega rikast rahvaluuleteadmist. Seda vabamad käed andis see fantaasiaküllasele ja kodufilosoofilisele lähenemisele isiku puhul, kes oma enesepilti ja minaidentiteeti korduvalt katkestas, muutis ja sünteesis, seda iga kord uute sümbolitega täites. Karl Tõnissoni uurija Mait Talts (2003) osutab, et K. Tõnisson fantaseeris eluloo teemal ja võltsis seda pidevalt. Igatahes moodustavad lendleht ja avaldatud raamatud elulooga ühe terviku. Lendleht vahendab usulisi mõtisklusi, viimsepäeva kuulutust, reflekteerib muutuva identiteedi konkreetse etapi tekstuuri ja sisu.

Tema järgnevad kirjutised moodustavad terviku muudetud identiteedi ja elulooga. Kokkupuuted Euroopas populaarsuse omandanud teosoofiaga, millega ta tutvus Riia ja Venemaa rännuaastail, ja Venemaa avarustes kogetud lähemad kokkupuuted budismiga muutsid mentaalsust. 1923. aastal pöördus ta Petrogradist, rahvaste Paabelist ja punaideoloogia keskusest Läti kodakondsusega tagasi Eestisse. Mait Taltsi andmetel ei andnud Eesti saatkond talle naasmisluba, sest tal oli kavas hakata budismi kuulutama.

Oma trükistes, eriti 1920. aastate lõpul ilmunud pisiväljaannetes tutvustab Tõnisson muistsete Balti rahvaste päikese- ja piksekultust, milles ta leiab sarnasusi vedade ja konkreetsemalt budistliku maailmavaatega. Väsimatult põimib ta trükistesse oma konflikte kohaliku ühiskonnaga ja unistusi tulevikust. Ta jäigi oma elust ja ühiskonnast luulevormis kõnelevate külapoeetide mentaalsuse kandjaks ja esindajaks. Liialdustega tembitult ja teravdatult annab ta edasi tõsielu ja fantaseerib, olles osalt originaalne, palju enam aga oma ajastu mõttevoolude ja rahvalike seisukohtade ruupor. Enese ihu imetlemine ja vaimu esitlemine on tema kirjatööde ühisjoon, samuti nagu oma seisukohtade vastandamine kristlaste "selgroolisele jumalale".

Olen esimene Buddha preester Balti mere rannal. Minu ametlik ehk ilmalik nimi on - Karlis Tennisons, - munga ehk vaimulik nimi-Vahindra. Olen ristiusulise Eesti rahva massilt tagakiusatud ja väljanaerdud, kui 
röövel, varas, tapja, põletaja jne... ning lisaks sellele veel hullumeelsekspaljasjalgseks paganausu papiks tõrvatud.

Olen evolutsionist, aga mitte revolutsionäär. Olen idealist ja erilise spordi harrastaja sportlane. Olen Tiibeti kerjusmunkade ordu "Sangha" liige. Olen filosoof ja esimese Buddhistliku filosoofia levitaja apostel kolmes praeguses Balti riigis: Latvijas, Lietuvas ning Eestis. Olen neonationalist ja neoantisemiit.

Ja siis ei või meid tulevikus

Ei must ei punane põrgu iialgi hirmutada.

Siis kaugest idast ilmub

Meil veel kord Džingiskhan.

Turani rahva keiser,

See kuulus Tammerlaan.

Omausundist rääkides toob ta esile selle ideaalseid külgi, osutab rahva raskele minevikule, mis tema arvates ei ole ikka veel minevik, vaid kestab ka 1920. aastate olevikus. Mait Talts on osutanud veel ühele Euroopas sel ajal pead tõstvale populaarsele liikumisele - 1920. aastatel levisid omausundid poliitilisele ja identiteedilavale ning algas laiem paganluse propageerimine ja harrastamine. Sellesse viimsepäevakuulutusejärgsesse aega kuulub paganluse loomine ja sulatamine budismiga talle ainuomasel kombel. Kirjatööd sobivad osaliselt samaaegse omausundit loova kirjasõnaga. Temal domineerib kolme

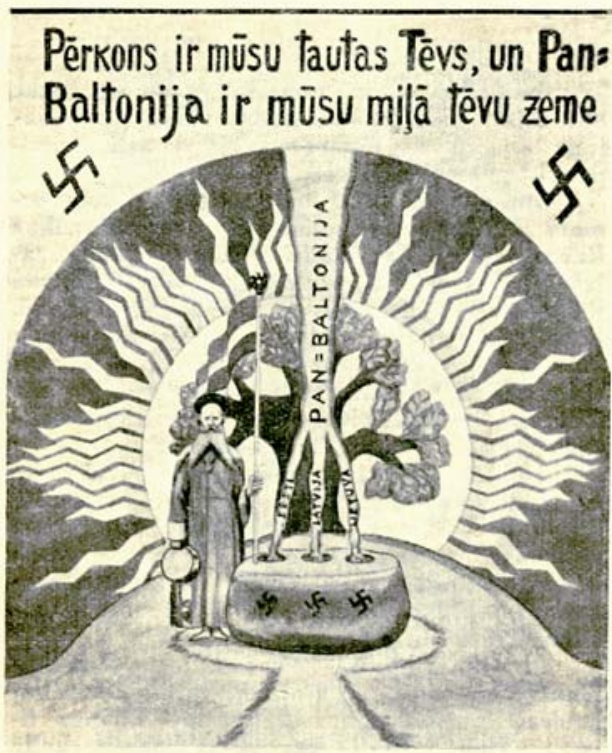

Müsu senču svētais upura akmens. riigi mütoloogiate esindamine üheskoos budismiga. Vend Vahindra nime all kirjutab ta pisitrükises Tulevane Pan-Baltoonia Ilmariik ja selles kuldses riigis asuvate Buddha-, Päärkonsi, Pikse- ehk taarausu preestrite seadus:

Illustratsioon 3. K. Tõnissoni pisitrükise kaanekujundus. 
[---] kui teie pooldate patriotismi ehk õiget isamaa-armastust, siis palun ostke see raamat, ja uskuge minu ennustust ja teadke, et on tulemas Baltimere ranniku rahvaste muistsed paganlikud rahvuskangelased ehk inimjumalad, nende rahvaste endised ning ajaloolised vahvad või vägevad juhid, kes rü̈̈tlite ehk juudijumala ustavate sulaste ehk ristiusu levitajate vastu armutumalt võitlesid ning rahvuslikku usku kaitsesid viimse veretilgani, nagu olivad eestlaste-liivlaste ja lätlaste-leedulaste muistsed rahvus-kangelased: Läti, Liivi sõjavägede tolleaegne ühine ülemjuhataja Imanta, eestlaste kangelane Lembit ja leedulaste muistne kangelane ning kuningas Gediminas (Vahindra 1928).

Karl Tõnissoni hilisemates kirjatöödes sulandub võitlev kristlusevastane (mille ta on osanud muuta ennekõike juudivastaseks hoiakuks, nagu ta ignoreeris sajandi alguses elamist suure Venemaa ilmariigi alamana) stiil fantaasiate ja kultuuritekstide vaikimisi imiteerimise ja tsiteerimisega. Trükises Mina ja minu jüngrid usume nõnda kirjutab ta näiteks:

Meid Taara ehk Päärkons aitamas, me ootame õigluse riiki. Meil PanBaltoonia loomiseks pole tarvis püssi ega piiki. Me ootame Imanta ilmumist, siis vaob me vaenlaste vari. Siis kaovad kõhklejad, kahklejad ja kelmide juutide kari.

Oh, Eesti, Läti, Leedu, kurb on su minevik! Ma kuulutan, kord tuleb sul kuldne tulevik. Nü̈d kümme aastat käidud meil vabaduse teed, Kuid usu orjapõlves on Balti rahvad veel.-

Oo, tule tuulekene ja pühi pimedus,

Et Balti palve-hääled

veel kajaks Hiie puus... (Vahindra 1930).

Sagedasti kasutab ta uuemale rahvalaulule omast värsivormi, lihtsaid riimimisvõtteid ja stereotüüpseid väljendeid oma ideede edastamiseks:

Hom mani Patme Hum

Suur Buddha kaitse Baltimaad,

Me isa-ema hällimaas,

Meid Balti ema sünnitand

Ning Balti pind meid kasvatand.

Ma Buddha jünger naeratan,

Kui piinab, mure, rist,

Mul Eesti rahvas pununud

On pärja ohakaist (Vahindra 1927). 


\section{Kokkuvõtteks}

Prohvetite ajaliselt piiratud ennustuste kõrval on piisavalt neid, mida rahvasuu/ suuline pärimus edastab ajast aega seotuna erinevate prohvetitega. Enamasti olid need poliitiliste ennetena käsitletavad ütlused, rahvapärase seletusprotsessi osa, mis pakkusid lootust teistsugusele tulevikule. Venemaa kuivab kokku ja on kord hobuseraua kujuline. Rootsi võidab. Tuhandeaastane rahuriik ei saa enne tulla, kui Vene tsaar Kremli aknast tsaaririigi piirid ära näeb, balti parunite lahkumine - need on ennustused, mida on omistatud taevakäijatele, Järve Jaanile, Kordole. Viimati omistati Äksi nõiana tuntud Hermiine Jürgensile (1892-1976) 1980. aastatel ütlus, et Kremli aknast näeb Venemaa piiri. H. Jürgens polnud prohvet, vaid selgeltnägija võimetega daam Tartu lähedusest, kes abistas enamasti kadunud isikute leidmisel. Poliitilised utoopiad ja lootused, mida prohvetite lausungite vahendusel meenutati, pakkusid ka alternatiivseid ajaloo käsitlemise võimalusi.

Osa korduvennustustest, nagu Kordo "Riiast Pihkvani ei kuule kuke laulu ega koera haukumist. [---] kui inimene sattub teise inimese jälgedele, hakkab nutma", kuulub stereotüüpsete muistendivormelite hulka. See oli varem katkumuistendite lahutamatu motiiv, mis kujutas, kui jubedast tühjusest algas uue elu loomine pärast taudi laastustööd.

Eesti prohvetite ennustused ja nägemused tuginevad rahvatraditsiooni kõrval piiblile või on sellele lähedased (vt Kalkun 2006: 813). Keel, metafoorid ja sümbolid, mida kasutavad erinevate sajandite usuformuleerijad, on rangelt seotud oma ajastu ja konfessiooniga. Näiteks on varasemates prohvetiseeringutes tavapärane, et prohvet esitleb ennast Kristuse pruudina ja kogu kuulutuse semantika on Kristuse-keskne (Salve 2000). 19. sajandi lõpu ja 20. sajandi prohvetite retoorika on hoopis teistsugune, oluline osa on argumenteerimisel.

Paljusid erinevate sajandite Eesti prohveteid võime iseloomustada kui kirjaprohveteid: nad on pannud oma seisukohti ja kogemusi kirja ja nende sõnumeid on ka kirjalikult levitatud. Selles suhtes sobib K. Tõnissoni lendleht autoriseeritud jätkuks pikemale traditsioonile. On tunnuslik, et veel 20. sajandi alguses on prohvetiseeringud moraali ja usu kõrval seotud ka taevastele nähtustega.

Mitmed prohvetid on tõusnud esile keerulistel ja majandusliku ebaedu aegadel. Siiski ei ole prohveti tegevus ega esilekerkimine kuidagi seotud üksnes väliste, sotsiaalpoliitiliste, majanduslike ja identiteediküsimustega. Need on seotud usuliste muutustega või vajadusega nende järele. Küll aga on prohvetite käitumine ja sõnumid olnud tõukeandjaks uuendustele. 
Lendleht maakera viimastest minutitest esindab loogilist osa rahvakristlikest vaadetest ja on lõimitud raamatukultuuri, ajalooteadmiste ja piibliga. Vanaeestlaste usundit K. Tõnissonile sobiva süsteemina ei olnud olemas, mistõttu see tuli tal ise formuleerida, väärtustada ja sellele omistada kindlad eetilised kategooriad. Kogu kirjategevus ja budismi-paganluse segune kihutustöö toimus sekulariseerunud ühiskonnas, mille liikmed otsisid uusi viise usu väljendamiseks ja enda sidumiseks sellega. Ometi viitavad Karl Tõnissoni kirjutised tunnetele ja väärtustele, mis erinevad ümbritsevast hegemoonilisest sotsiaalsest diskursusest. Ajakirjanduse uudiste rubriik edastab lugejatele teateid sünkretismile püüdlevatest budismi ja muinaseesti usundi ühendusest tulenenud sündmustest, hiiemetsa tantsudest ja plastilise gümnastikaga pikitud loengutest. Neid täiendavad trükised, kus K. Tõnisson enesekeskselt esitleb oma "laitmatut ihu" selle alastuses. Ta teavitab budistliku pühamu asutamisest Riias ja budismi õpetusest, ent teeb seda oma veidral moel. 1930. aastal rändas ta koos jüngri ja eluaegse kaaslase Friedrich V. Lustigiga (budistliku nimega Ashin Ananda) Pariisi ja sealtpeale otsesed kontaktid Eestiga katkesid.

K. Tõnisson vahendas ühiskonnale mitut sõnumit - usutõsiduse vajadust, budismi, teosoofilisi sulandeid erinevatest uskudest ja omausundit, mida alles formuleeriti.

Lugupidamisest ja usaldusest prohveti sõnumi vastu ei alluta paljud tema järgijad sümbolit analüüsile. Maurice Bloch nimetab lugupidamist inimelu üldiseks aspektiks: "See ilmneb alati, kui teeme midagi või usume, et miski on tõsi, tuginedes teiste autoriteedile - me teeme seda pidevalt" (Bloch 2005: 135).

Artikkel on valminud SF0030181s08 raames.

\section{Arhiivitekstid}

\section{Eesti Rahvaluule Arhiivi käsikirjalised rahvaluulekogud}

H, Kase - Jakob Hurda rahvaluulekogu, 1860-1906.

RKM - Eesti TA Fr. R. Kreutzwaldi nim (Riikliku) Kirjandusmuuseumi (nüüd Eesti Kirjandusmuuseumi) rahvaluule osakonna rahvaluulekogu, 1945-1996. 


\section{Kirjandus}

Bloch, Maurice 2005. Essays on Cultural Transmission. London School of Economics monographs on social anthropology 75. Oxford \& New York: Berg.

Brasher, Brenda E. 2004. Give Me That Online Religion. New Brunswick \& New Jersey \& London: Rutgers University Press.

Eisen, Matthias Johann 1921. Eesti prohwet Järwe-Jaan. 2., täiend tr. Tallinn: A. Keisermann.

Gerodnik, Gennadi 1973. Vend Vahindra. Satiiriline dokumentaaljutustus [Eestis ja Lätis tegutsenud buda usu jutlustajast K. Tõnissonist]. Tallinn: Eesti Raamat.

Georgakopoulou, Alexandra 2007. Small Stories, Interaction and Identities. Studies in Narrative 8. Amsterdam \& London: John Benjamin.

Kalkun, Andreas 2006. Mart Saali ja Lüütsepa Jaani taevaskäigud: Protestantlikest ilmutustest, nende poeesiast ja motiivistikust. Keel ja Kirjandus 10, lk 797-815.

Kikas, Katre 2006. Väitlus tumma tekstiga: Hans Anton Schults ja Andres Saal. Hiiemäe, Mall \& Labi, Kanni (toim). Linna-alused. Pro folkloristica XIII, lk 18-41.

Kronk, Gary W. 2010. Meteors and the Native Americans. Farshores: Worldwide anomalous phenomena resource: Ancient mysteries (http://farshores.org/a03mnm.htm - 4. aprill 2010). The American Meteor Society (http://www.amsmeteors.org/comets/meteors/ metlegends.html - 22. oktoober 2010).

Kõiva, Mare 2007. Komeedid eesti rahvausundis. Kõiva, Mare (toim). Sator 6. Tartu: EKM Teaduskirjastus, lk 161-197 (http://www.folklore.ee/rl/pubte/ee/sator/sator6/ 22. oktoober 2010).

Masing, Uku 1993 [1934-1935]. Prohvet Maltsvet. Vaatlusi maailmale teoloogi seisukohalt. Tartu: Ilmamaa, lk 11-157. [Originaal Usuteadusline Ajakiri 1934, 4, lk 122 126; 1935, 1, lk 24-29; 2, lk 49-52; 1936, 3, lk 93-103; nr 4, lk 124-136; 1937, 3/4, lk 100-114.]

Põldmäe, Rudolf 1935. Taevakäijad. Kaleviste mailt. Õpetatud Eesti Seltsi kirjad 3. Tartu: Õpetatud Eesti Selts, lk 123-176.

Põldmäe, Rudolf 1937. "Se velle Lütseppa Jani ello käük siin ma pääl ehk sääl taivan”. Eesti Kirjandus 12, lk 611-618.

Salve, Kristi 1998. Kordo - nõid ja/või prohvet. Mäetagused: Hüperajakiri 8, lk 58-79 (http://www.folklore.ee/tagused/nr8/kordo.htm - 22. oktoober 2010).

Salve, Kristi 2000. Oh, kes saab lihakeelega üles rääkida taevased asjad! Mart Saali ilmutus. Mäetagused: Hüperajakiri 14, pp. 83-96 (http://www.folklore.ee/tagused/nr14/ ilmutus.htm - 2. aprill 2010).

Sild, Olaf 1929. Tallima Paap. Usuteadusline Ajakiri 3/4, lk 97-129.

Sild, Olaf 1935. Üksikasju taevakäijate liikumisest mõningate säilinud kohtuaktide valguses. Usuteadusline Ajakiri 4, lk 109-120. 
Stewart, Kathleen \& Harding, Susan 1999. Bad Endings: American Apocalypsis = Mauvaises fins: Apocalypse américaine. Annual Review of Anthropology 28, lk 285310 .

Space Science 1999. The Great Leonid Meteor Storm of 1833: A first-hand account by Elder Samuel Rogers. Space Science News Archive (http://spacescience.spaceref.com/ newhome/headlines/ast22jun99_2.htm - 22. oktoober 2010).

Talts, Mait 2003. “Esimene buda preester Baltimere rannikul...”: Karl August Tennison ja eestlaste esmatutvus budismiga. Akadeemia 7: lk 1421-1443; 8, lk 1618-1645.

Tennison, Karl August (= Tõnisson, Karl) 1907. Meie maakera wiimased minutid . Riia: [s.n.].

Vahindra, vend (= Tennisons, Kārlis = Tõnisson, Karl) 1927. Hom-Mani-Patme-Hung. Tartu: [s.n.].

Vahindra, vend (= Tennisons, Kārlis = Tõnisson, Karl) 1928. Tulevane Pan-Baltoonia Ilmariik ja selles kuldses riigis asuvate Buddha, Päärkonsi-, Pikse- ehk Taarausu preestrite seadus. Riga: $\mathrm{K}$. Tennisons.

Vahindra, vend (= Mahatma Vend-Vahindra = Tennisons, Kārlis = Tõnisson, Karl) 1930. Mina ja minu jüngrid usume nõnda. Rīga: Kārlis Tennisons

Valloton, Kris 2007. Halastus võidutseb kohtu üle (http://www.unity2007.net/template/ files/mdl_files.php/K.Vallaton__Halastus.doc - 22. oktoober 2010).

\title{
Summary
}

\section{The last Minutes of our Earth}

\author{
Mare Kõiva
}

Key words: end of the world, Karl Tõnisson, leaflet, prophecy, prophets, The Last Minutes of our Earth

The article seeks to compare popular omens of the end of the world with the auguries of prophets. Both traditions reflect societal and cultural changes, the fears for doomsday tend to integrate new interpretations and causes for destruction. Astronomic celestial phenomena retain their relevance whereas the recent discoveries in astronomy, physics, genetics and other sciences have remarkably complemented the list omens for the end of the world. Latter-day prophecies leashed by human behaviour and intellect, alien civilisations and other relevant motifs have come to the forefront during the last century. Prophetic predictions propose fixed dates, represent certain political or ideological trends, associated with social norms and evoked as a result of changes therein. Among the prophetic messages there are stereotypical expressions and omens which have been adapted and attributed to different persons. Karl Tõnisson's leaflet Meie maakera viimased minutid 'The Last Minutes of Our Earth', printed in 1907, is a 
political-apocalyptic contemplation based on scriptural passages substantiated by references to scholarly works, illustrated with five woodcuts. The omens of the end of the world, listed by the author, comprise an earthquake in Lisbon in 1795, a dark day in New England in 1780 and the 1833 meteor storm in America. The discussions presented in the leaflet differ from Tõnisson's later self-centred political fantasies on Pan-Baltonia, and the ideology and rhetoric of the booklets endeavouring to create a native religion merged with Buddhism. 